\title{
PROTECTION OF ENVIRONMENT THROUGH PUBLIC INTEREST LITIGATION IN INDIA: AN APPRAISAL
}

\author{
Shoyab Mohammad ${ }^{1}$ and Nafeesa Bano ${ }^{2}$ \\ ${ }^{1}$ Assistant Professor, Govt. Law College, Bundi (Rajasthan) India \\ ${ }^{2}$ Assistant Professor, Government Law College, Ajmer, (Rajasthan) India \\ Email: shoyab.d.best@gmail.com, banonafeesa9@gmail.com
}

\begin{abstract}
Environment pollution is a burning problem not only in India but also in the world. The need to protect and improve the environment is so compelling for the peaceful survival of mankind and other life forms on Earth. Indian Constitution contains provisions to protect the environment, and various legislations pertaining to environmental laws have been incorporated by the Indian Parliament. Indian Judiciary has played an extensive and innovative approach to protect the environmental rights in the country specifically to entertain the Public Interest Litigations on environmental issues. Over the years most of the environmental issues are raised through Public Interest Litigations in India. Several judicial decisions have been given by Supreme Court and High Courts to safeguard the environment on Public Interest Litigations. Now days Public Interest Litigations have become an effective tool to protect the environment in India.
\end{abstract}

Key words: Environment Pollution, Environmental Laws, Public Interest Litigation.

\section{Introduction}

The Protection of environment is a burning issue and whole word is suffering due to this issue. Administrative and legislative strategies of harmonization of environment values with developmental values are a must and are to be formulated in the crucial of prevalent socio economic conditions in the country. In determining the ambit of the powers and duty of administrative agencies and in making a balance between the environment and development, the courts have a crucial role to play. Judicial activism especially Public Interest Litigation (PIL) is playing a significant role for safeguarding environment. Justice $\mathrm{P} \mathrm{N}$ Bhagwati is known as the father of PIL in India. Several Judicial decisions have been given by the Supreme Court and High Courts for this purpose. Right to get pollution free air, water, etc. have been included in the guarantee of Article 21 namely Protection of life and personal liberty. PIL may be taken as a tool for a legal action initiated in a court of justice for the enforcement of the public interest or general interest in which the public or a group of the community has monetary interest or have some interest because it will affect their legal right or liabilities. In Janta Dal v. H.S. Choudhary AIR 1993 SC 892, PIL has been defined as a legal action initiated in a court of law for enforcement of public welfare or public interest in which the general public or a group of the public have monetary interest or some other interest by which their legal rights or liabilities are affected. Preamble of the Constitution emphasizes on Equality of status and of opportunity and equal justice to all persons. Article 14, 21, 38, 39A of Indian Constitution plays a significant role in the development of PIL. PIL today has great significant and drew the attention of all concerned. The traditional rule of "Locus Standi" that a person, whose right is encroached alone can file a petition, has been noticeably relaxed by the Supreme Court in its recent decisions. Now, the court permits PIL at the instance of public spirited citizens for the enforcement of constitutional-legal rights. Now a day there has been a boom of environmental litigation. Presently most of the issues related to environment in India are brought under Article 32 and 226 of the Constitution through PIL. The writ procedure is preferred over the ordinary suit because it is fast, relatively less expensive and offers direct access to the highest courts of the country. The powers of the Supreme Court to issue directions under Article 32 and that of the High Courts under Article 226 have gained greater sense in environmental cases. Courts have made use of these powers to relief past dissembling and to analysis immediate and future danger to the environment. 


\section{Environment Protection: Indian Legal Provisions}

Environmental pollution is one of the most serious problems facing humanity and other life forms on our planet today. India in June 1972 took participation at the United Nations Conference on the Human Environment held at Stock-holm, to take appropriate steps for the protection and improvement of human environment, further to implement the decisions of Conference Environment (Protection) Act, 1986 is enacted by Parliament in India. This Act includes all forms of pollution water, air, soil and noise. It provides the safe standards for the presence of various pollutants in the environment. It prohibits the use of hazardous material without prior permission is taken from the Central Government. It allows the central government to give authorities a range of jurisdictions to carry out the laws of this Act. "Environment Pollution" means the presence in the environment of any environmental pollutant as per Environment (Protection) Act, 1986, Section 2 (c). In simple words Environmental pollution is defined as "the contamination of the physical and biological element of the earth to such a degree that normal environmental processes are negatively affected. The main objective of laws related to environment protection is to save the human generation and promote the healthy life. Indian Constitution contains certain articles related to safeguard the environment and Indian Parliament has been enacted certain laws for the protection of environment. Constitutional provisions regarding safeguarding to environment are:

- Article 14: Equality before law- The State shall not deny to any person equality before the law or the equal protection of the laws within the territory of India. Equality before the law and equal protection of the law has been granted under article 14 of the Constitution. This fundamental right impliedly casts a duty upon the state to be fair while taking actions in regard to environmental protection and thus, cannot infringe article 14. In cases of exercise of arbitrary powers on behalf of the state authorities, the judiciary has played a strict role in disallowing the arbitrary sanction. Use of discretionary powers without measuring the interest of the public violates the fundamental right of equality of the people.

- Article 21: Protection of life and personal liberty- No person shall be deprived of his life or personal liberty except according to procedure established by law. Article 21 has been liberally interpreted by the Supreme Court in Maneka Gandhi v. Union of India AIR 1978 SC 597 case. Article 21 guarantees right to life as a fundamental right. Right to life includes right to healthy environment as an important attribute of right to live with human dignity.

- Article 48A: Protection and improvement of environment and safeguarding of forests and wild life- The State shall endeavour to protect and improve the environment and to safeguard the forests and wild life of the country. This article was added in Constitution by the $42^{\text {nd }}$ Amendment Act, 1976. In M.C. Mehta (II) v. Union of India (1988) 1 SCC 471 the Supreme Court, relying on Article 48A gave directions to the central and the State Government and various local bodies and Boards under the various statutes to take appropriate steps for the prevention and control of pollution of water.

- Article $51(\mathrm{~g})$ : It shall be duty of every citizen of India, to protect and improve the natural environment including forests, lakes, rivers and wild life, and to have compassion for living creatures. This duty incorporated in the Constitution by the $42^{\text {nd }}$ Amendment Act, 1976, and shall be enforceable by law.

Besides Constitutional provisions some Environment laws have been enacted for the protection of environment in India. These are followings:

1. The Indian Forest Act, 1927

2. The Wild Life ( Protection) Act, 1972

3. The Water (Prevention and Control of Pollution) Act, 1974

4. The Water (Prevention and Control of Pollution) Cess Act, 1977 \& 2003

5. The Water (Prevention and Control of Pollution) Cess Rules, 1978

6. The Forest (Conservation) Act, 1980

7. The Air (Prevention and Control of Pollution) Act, 1981

8. The Ganga Action Plan 1986

9. The Environment Protection Act, 1986

10. National Water Policy 1987, 2002, 2012

11. The Public Liability Insurance Act, 1991

12. The National Environmental Tribunal Act, 1995

13. Recycles Plastics, Plastics Manufacture and Usage Rules, 1999

14. The Noise Pollution (Regulation and Control) Rules, 2000 
15. Batteries (Management and Handling) Rules 2001

16. The Biological Diversity Act, 2002

17. National Environment Policy 2006

18. The Scheduled Tribes and Other Traditional Forest Dwellers ( Recognition of Forest Rights) Act, 2007

19. Hazardous Wastes (Management and Handling) Rules, 1989, 2002, 2003, 2008 and 2016

20. The National Green Tribunal Act, 2010 etc.

\section{Protection of Environment through PIL in India: An analysis}

In our legal system Supreme Court is known as guardian of Constitution. So, through interpretation, in so many cases Supreme Court has given the matter of "environment protection" at high priority level. Actually in this regard role of judicial activism specifically Public Interest Litigation (PIL) is notable. The efforts of the highest Court in environment protection through PIL is indeed laudable particularly when the Legislature is fall behind in bridging the gap in the existing legal system and administration is not well equipped to meet the challenge. Several historical judicial decisions have been given by the Supreme Court for the protection of environment. Here I am mentioning some landmark judgments on PIL for the protection of environment. In Rural Litigation and Entitlement Kendra v. State of U.P. (1985) SCC 431, the Court ordered to close certain lime stone quarries on the ground that there were severe failing regarding safety and security in them. The Court appointed a committee for inspecting certain lime stone-quarries. The Committee proposed the closure of certain classes of stone quarries having regard to bad impact of mining operations therein. A large scale pollution was induced by lime stone quarries badly affecting the health of the people residing in the locality.

In M.C. Mehta v. Union of India, (1986) 2 SCC 176, ( Shriram Food and Fertilizer case) the Supreme Court directed the company manufacturing hazardous and noxious chemicals and gases danger to health and life of workmen and people living in its area, to take all necessary safety measures before reopening the plant. There was a leakage of Chlorine gas from the plant resulting in death of one person and causing difficulty to workers and residents of that area. This was due to negligence of the management in maintenance and operation of the caustic chlorine plant of the company. The matter was brought before the Court through a PIL. The case lays down the principle of absolute liability that where a person establish an industry of dangerous nature then he is responsible completely for danger created by it. In M.C. Mehta v. Union of India, (1987) 4 SCC 463, the Supreme Court ordered the closure of tanneries at Jajmau near Kanpur, polluting the river Ganga. The matter was brought to the notice of the Court by the Petitioner, a Social worker, through a PIL. The Court held that in spite of the provisions contained in the Water (Prevention and Control of Pollution) Act and the Environmental (Protection) Act, no effective action were taken by the Government to stop the serious public nuisance caused by the tanneries at Jajmau, Kanpur. In the circumstances, it was held that the Court was entitled to order the closure of tanneries unless they took steps to set up treatment plants. In Damodar Rao v. S.O. Municipal Corporation AIR 1987 AP 171, Court held that the environmental pollution which is slowly polluting the atmosphere should also be regarded as amounting to violation of Article 21 of the Indian Constitution.

In Rural Litigation and Entitlement Kendra, Dehradun v. State of Uttar Pradesh AIR 1987 SC 2187, Supreme Court introduced the concept of "Sustainable Development" it was held that the durable assets of humankind are not to be consumed in one generation. The natural resources should be used with proper attention and care so that ecology and environment may not be adversely affected. In L.K. Koolwal v. State of Rajasthan AIR 1988 Raj. 2, the Rajasthan High Court observed that a citizen's duty to protect the environment under Article $51-\mathrm{A}(\mathrm{g})$ of the Constitution confer upon the citizens the right to clean environment. In M.C. Mehta v. Union of India AIR 1988 SC 1115, (Ganga River Pollution Case) The River Ganga is very famous for its historical significance and religious importance. It got polluted due to discharge of industrial wastes, effluents, human excreta into the river. Further, a number of dead bodies are being discharged into the river at Kasi, with a belief that the deceased would go to heaven directly since they consider Kasi as a holy place and the river as sacred. The petitioner M.C. Mehta, Advocate Supreme Court filed a PIL petition in the Supreme Court under Art. 32 of the Constitution against the Union of India, Kanpur Municipal Corporation and others for removal of public nuisance caused due to polluted Ganga water, The Supreme Court permit the writ 
petition and give directions to concerned authorities to take up necessary steps for removal of the public nuisance and also appreciated the petitioner for taking initiative in this regard. In Subhas Kumar Kumar v. State of Bihar AIR 1991 SC 420 it has been held that PIL is maintainable for ensuring enjoyment of pollution free water and air which is comprised in the "right to live" under Article 21 of the Constitution. In M.C. Mehta v. Union of India AIR 1992 SC 382 Supreme Court issued certain directions to the Government of India to propagate education on environmental pollution. The Educational Boards were directed to take appropriate steps to enforce compulsory education on environment up to matriculation from the next academic year and the University Grant Commission to consider the feasibility of making environment a compulsory subject at every level in college education. In Vellore Citizens Welfare Forum v. Union of India and other AIR 1996 SC 2715, The petitioner filed a public interest litigation petition under Art. 32 of scale pollution caused to the river Polar due to the discharge of untreated effluents by the tanneries and other industries in the state of Tamil Nadu. The Court appointed a committee to report on the matter. The Supreme Court after examining the report-submitted by the Committee delivered its judgment making all efforts to maintain a balance/harmony between economic development of the people on one hand and welfare of the people on the other. The Court held that sustainable development is a balancing concept between ecology and development. In this case Supreme Court propounded the principles, "the precautionary principle" that is, "polluter pays" and this principle has become the law of land as by virtue of Article 141 of the Constitution. "The polluter pays" principle as explained by Supreme Court means that the absolute liability to harm the environment expand not only to compensate the victims of pollution but also the cost of restoring the environment degradation.

In Indian Council for Environment Legal Action v. Union of India (1996) 5 SCC 281, PIL filed by registered voluntary organization for economic degradation in coastal area. Supreme Court issued appropriate orders and directions for enforcing the laws to protect ecology. In M. C. Mehta v. Kamal Nath \& Others, 1997 (1) SCC 388, the Supreme Court propounded the doctrine of public trust, the trust of that theory is that natural resources such as seashores, forests, rivers and the air are held by the Government in trusteeship for free and unimpeded use of the general public. Resources like air, sea, water and the forests have great importance to the people all together, that it would not be proper to make them a subject of private property. However, state as a custodian of natural resources has a duty to maintain them not merely for the benefit of public, but for the best interest of flora and fauna, wild life and so on. The doctrine of public trust has to be addressed in that perspective. In M.C. Mehta v. Union of India AIR 1998 SC 2963, The Supreme Court issued directions for checking the vehicle pollution in Delhi. In another case of Church of God (Full Gospel) in India v. KKR Majestic Welfare Association AIR 2000 SC 2773, the Supreme Court held that noise pollution amounts to violation of Article 21 of the Indian Constitution. In Namada Bachao Andolan v. Union of India and Ors AIR 200010 SCC 664, the Supreme Court of India upheld that "Water is the basic need for survival of mankind and is part of the right to life and human rights under Article 21 of the Constitution and the right to healthy and pollution free environment and to sustainable development are fundamental human rights implied in the right to life.

In M.C. Mehta v. Kamal Nth AIR 2000 SC 1997, the Supreme Court has held that environment pollution is a tort against the community and the Court, in Proceedings under Article 32 or 226 can levy exemplary damages on the person found guilty of disturbing the environment. In case of M. C. Mehta v. Union of India AIR 2001 SC 1948, Supreme Court observed that air pollution in Delhi caused by vehicular emissions violates right to life under Article 21 and ordered all commercial vehicles operating in Delhi to switch to CNG fuel for safeguarding health of the people. In a landmark judgment in Intellectual Forum Tirupathi v. State of Andhra Pradesh AIR 2006 SC 1350, the Supreme Court has held that under Article 21 and Article $51 \mathrm{~A}$ it is the constitutional obligation of the Government to protect and preserve the environment. In the name of urban development environment cannot be impaired. In Indian Council for environ-legal Action v. Union of India AIR 2011 Vol. 8 SCC 161, Supreme Court felt that such conditions in different parts of the country being better known to them, the high courts would be the proper forum to be moved for better implementation and monitoring of the antipollution law. In Bhopal Gas Peedith Mhila Udyog Sngathan v. Union of India AIR 2012 SC 3081, the Supreme Court directed Union of India and State of Madhya Pradesh that the huge toxic materials/waste lying in and around the factory of Union Carbide Corporation Ltd. In 
Bhopal, the existence of which was hazardous to health, needing to be disposed of at the earliest, to be disposed of within six months which should be strictly in a scientific manner which may cause no further damage to human health and environment.

Recently Supreme Court of India in the case of M.C. Mehta v. Union of India \& Others ordered on dated 06 September 2019 regarding air pollution in Delhi aggravated by stubble burning. The Supreme Court of India directed that the small and marginal farmers who have not burnt the stubble in the states of Punjab, Haryana and western Uttar Pradesh be provided financial support of Rs. 100/- per quintal of non-basmati paddy within seven days by the state government. The states have to provide the machines which will take care of the stubble like happy speeders, hydraulically reversible MB plough, and paddy straw chopper to the farmers who cannot afford the machines for the time being free of cost and submit an action taken report in one month. SC directed to Central Government, Government of NCT of Delhi, Haryana, Punjab and Uttar Pradesh to take necessary actions regarding to prevent air pollution in Delhi aggravated by stubble burning. The Supreme Court and High Court's decisions on Public Interest Litigations shows the activeness of judiciary for the safeguarding the environment. Now a day's most of the environmental issues are raised through PIL in India. The Supreme Court and High Courts time to time issues directions and guidelines to government for safeguarding the environment on PIL. So it would not be wrong to say that PIL is playing crucial role to protect the environment.

\section{Conclusion}

The Problem of environment pollution has been recognized as a worldwide disaster. The environment protection needs instant attention globally. In India for the protection of environment provisions are given in Indian Constitution, apart from these provisions number of acts have been enacted by Parliament for the protection of environment. Indian Judiciary has played very important role in the protection of environment. It has broadened the existing legal provisions to address the environmental issues. It has evolved new principles and doctrine to deal with environment problem. Indian judiciary progressively enlarging the scope of a qualitative living by taking initiatives to resolve various issues of environmental protection. Thus, activities posing a danger to the environment were curtailed so as to protect the one's inherent right to a healthy environment as guaranteed under Article 21 of Constitution. Now a days PIL has developed as an effective tool in the area of environmental protection. In a PIL, a public spirited person or class of persons or an organization can move to court for filing a petition on behalf of poor and ignorant individuals. The Indian judiciary has used the PIL as a tool for the cause of environmental protection in many cases. Supreme Court and High Courts have been given many landmark judgments, directions, and orders and issued guidelines from time to time to check the menace of the environmental pollution on Public Interest Litigations. In Murali S Deora v Union of India Case Supreme Court declared the pollution caused by smoking, is violation of Article 21 of the Indian Constitution. At present time most of environment issues are raised through PIL in India. Supreme Court is discharging its duty very well to protect the environment and human health, but it is not only duty of judiciary to protect the environment but it is duty of every citizen to protect the environment.

\section{References}

1. Bakshi's P.M. (2006) Public Interest Litigations. Ashoka Law House, New Delhi.

2. Malik S. (2012) Environmental Law, Eastern Book Company, Lucknow.

3. Pandey J.N. (2014) Constitutional Law of India, Central Law Agency, Allahabad.

4. Rai K. (2003) Public Interest Lawyering, Legal Aid and Para-Legal Services, Central Law Publications, Allahabad.

5. Tripathi G.B. (2013) Constitutional Law-new challenges, Central Law Publications, Allahabad.

6. Tripathi, S.C. (2017) Environmental Law. Central Law Publications, Allahabad.

7. Upadhyaya J.J.R. (2015) Environmental Law, Central Law Agency, Allahabad. 